\title{
OPPRESSION ON THE BIRHOR TRIBE IN JHARKHAND, INDIA: A CASE STUDY
}

\author{
Charu Kriti* \\ National University of Study and Research in Law, Ranchi, India
}

Email:*kriticharu@gmail.com

\begin{abstract}
Oppression is, by far, not a new phenomenon. Since times immemorial there have been stories of oppression, told and retold. The oppressed tell the stories from their perspective, where they are the downtrodden and exploited. The oppressors, on the other hand, glorify their actions as powerful and the way the oppressed were meant to serve them. No matter what the perspective, no matter what the time, one sector showing its power over another has been a common occurrence. This paper is an attempt to outline this never changing and everlasting occurrence of oppression. The paper covers a present day incident of oppression on a scheduled tribe in the state of Jharkhand, India, called the Birhor Tribe. The paper looks at the conditions of the tribal people, their oppression by authorities and people in power and their day to day struggle. The paper finally tries to explain the current form in which oppression occurs with the help of established psychological theories.
\end{abstract}

Keywords: Oppression, Present day Oppression, Psychology of Oppression, Birhor Tribe

\section{Introduction}

There is nothing permanent except change. This philosophy of Heraclitus has been quoted, generation after generation, to emphasize on the ever changing world around us. Whenever the study of any phenomenon with respect to its current trend is attempted, the social, political and economic changes are always taken into account, because change is permanent. Yet, there are certain behaviours that do not change with the world. They might be modified in their implications, but they still exist. The form changes, but the entity remains. Oppression is one such behaviour.

How can oppression best be defined? Psychologically speaking, it refers to a state or pattern of behaviour which stratifies one as strong and the other as weak. Oppression originates from the Latin term opprimere which means to press down. Sociological perspective defines it as a social act in which a severe restriction is placed on an individual, group or institution by an organization in power. The Webster dictionary defines it as "Unjust or cruel exercise of authority or power especially by the imposition of burdens; the condition of being weighed down; an act of pressing down; a sense of heaviness or obstruction in the body or mind."

Notice that each of the above definitions talks about two groups, the group that is oppressed and the group that is oppressing the first one. In 1983, Marilyn Frye wrote an extensive chapter on oppression on women. She defined oppression on the basis of five necessary conditions that must occur if the act has to be called that of oppression. First, she mentions that the person needs to be restricted by barriers or limitations. Second, these restrictions must be harmful and the person must suffer on account of them. Third, it must be the social structure or institutions that impose these restrictions. Fourth, the restrictions must have been imposed in lieu of the membership of the person in a particular social group. Finally, there must be a different social group which gains from the restriction upon the social group and must also impose restrictions on other groups.

Thus, oppression is a two-way street. And there is always one party which gains from it while the other suffers. The form in which oppression occurs in the society differs in different situations. The most common forms that we study today are sexism, classism and racism. This paper is an attempt to explain the process of oppression as 
a constant occurring pattern in the society and the structure of oppression. A case study is presented in the paper, which elaborates upon the process and structure of oppression in the present times. The same is analyzed on the basis of the psychological explanation and the sociological history of oppression.

How often do we come across people who refuse to call a spade a spade, and justify acts of oppression as simple social stratification? Social stratification does, in fact lie at the base of oppression. Not because it is synonymous to the latter, but because it is the structural cause for it. In the above definitions, where the two groups are referred to, the reference of socially determined groups is being made, created by the process of stratification of the society. Pick up any form of oppression, the socially stratified groups can be easily determined. Sexism refers to discriminating against women. Had the gender classification not been of social significance, there would have been no roles assigned to either. Racism would not have been a problem if ethnicity did not classify the society and classism would have created no turmoil if the upper class did not enjoy certain privileges, of which the working class was deprived.

So we start with stratification. Social stratification is a process that explains the social inequalities and groups similar people in the same strata. The basic tenet states that stratification is variable in nature, but is universal. Thus, there has always existed in society, division of people on the basis of different factors that determine the membership of each group for each individual. It is the same groups that Myers (1990) talks about. Now that $t$ is clear that stratification is not a novel concept, let's delve into the cause behind oppression.

The understanding of oppression can be related to power and privilege of one over the other. If the first occurrence of this state of affairs is dug up, it will probably lead to the time of the early men, where, for the first time, one man must have picked up the stick and claimed his possession on a piece of land or on an animal or even a woman in the clan. Judith Butler explains the connection between the two factors that probably are the foundation of such behaviour, the knowledge of vulnerability in humans and the exposure and understanding of violence (Gilson, 2011).

When the concept of oppression is explored, many equate the terms prejudice and discrimination with the different forms of oppression (Bohmer and Briggs, 1991). But oppression is not necessarily the story of absolutely helpless people against that of the privileged winners (Bohmer and Briggs, 1991). To get a clear picture it is important that a more inclusive view is taken. The barriers that Myers (1990) emphasizes upon are not packed in air tight compartments. The barriers have to be understood as a comparison between the privileged and the oppressed (Bohmer and Briggs, 1991).

Understanding oppression from one single perspective would be a fallacy because the implication is at various levels. Only an interdisciplinary approach with regard to the psychology, the sociology and even the legal perspective of any act of oppression will serve as a comprehensive analysis (Prilleltensky\&Gonick, 1996). Over a period of time, oppression has become deep rooted in the institutions of the society. There exists a pervasive and systematic correlation between the barriers of different social institutions (Bohmer and Briggs, 1991). Take a family setting in a middle class Indian society for example. A son would be given more freedom than a daughter. There might also be instances where the son might be allowed to leave home for studies, but the same may not apply to the daughter.

Revisiting the question asked earlier; have you come across people who tend to diffuse the seriousness of oppression or counter it by arguing that even the oppressed show oppression? Has there been instances that men also are oppressed? Or where the argument states that oppression is a thing of the past because members of the oppressed groups are doing 'just fine'? A macroscopic view of oppression (Prilleltensky\&Gonick, 1996) enables the understanding that inequality of opportunity leads to the emergence of the two separate groups: the oppressed and the privileged. This view also offers an understanding that oppression is pervasive in nature (Bohmer and Briggs, 1991). 
However, this view doesn't exactly explain the magnitude of the problem. It is merely something more than the tip of the iceberg. Most importantly, it is not a problem of the past. The present day problem is more than just an act of oppression. It is non acceptance that oppression exists. It somewhere derives from the concept of implicit prejudice, where people hide their original feelings of prejudice in public settings, but present bigoted views in 'safe' situations (Baron, Byrne and Branscombe, 2008). And such mentality is harder to argue with, because the people holding them will never accept that they have such beliefs.

\section{The case of the Birhors in Jharkhand}

Taking an example of oppression as it exists today, let us talk of a nomadic tribe called Birhor. It is a tribe native to the state of Jharkhand, which lies towards the east of India. A fact finding team of human rights lawyers and activists visited the then settlement of the Birhors, called Birhortola, in Lohadanda, Block Jainagar, DistrictKoderma of Jharkhand in the year 2013. The basis of investigation was the news of death of the members of the tribe in rapid succession in a matter of months.

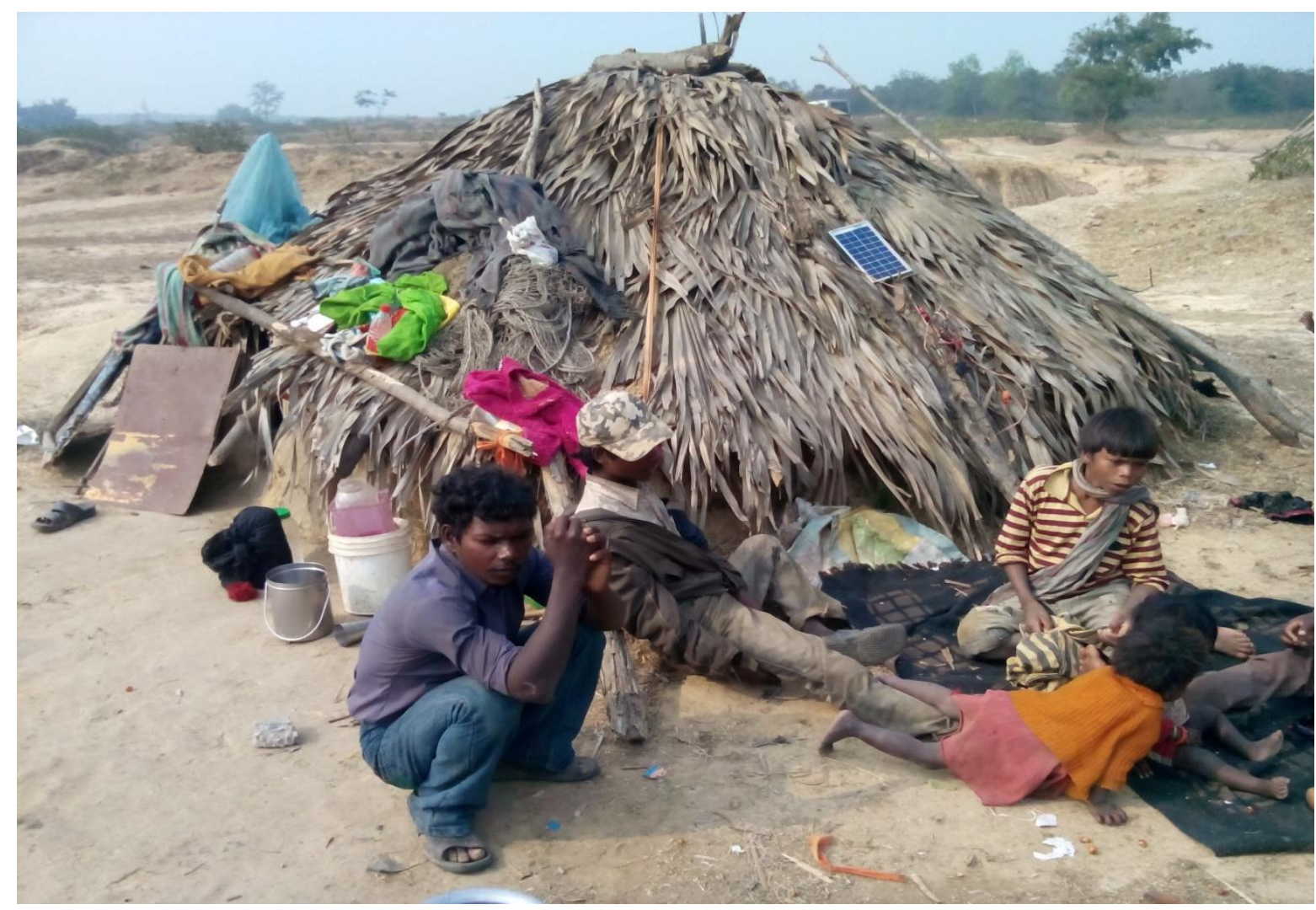

Figure 1: The huts where the members of the tribe dwelt

The team had no difficulty reaching the block nearest to the village. However, the last lap of the journey was more difficult than expected. The village of Birhortola was home for 150-200 people. And the settlement that the tribe had at this point of time was difficult to spot. Amidst minor sandstorms and many wrong turns and detours, the destination was finally found. Birhortola was a cluster of nine small huts, barely three feet in height, as shown in figure 1.The natives were all sitting outside in the sun, preparing meals, completing daily chores or just chatting. The method of the fact finding was an unstructured interview.

It was found that the conditions of food, water, hygiene, employment and other basic amenities were in piteous state. Wherever given a chance, the privileged group was ready to take advantage of the tribe. The point of focus of the interview was the recent deaths. It was found that despite many promises made to the members of the 
tribe by the local leaders and politicians during the last local elections, they still had no access to clean drinking water. The area that Birhortola was located is arid land and hence digging wells is not the most easily available option.

The people had raised this issue over and over again in front of the local block leaders and the state authorities, and had received numerous assurances of water tanks and tube wells and the likes being set up in the area. However, the remoteness of the area or probably the general 'forget the people after the elections have been won' concept, had led to no $n$ such set ups for drinking water. Hence, the members of the tribe had to 'build' a makeshift well from a nearby flowing river. It was the water of this well that had claimed the life of three young men and women in the past 6 months.

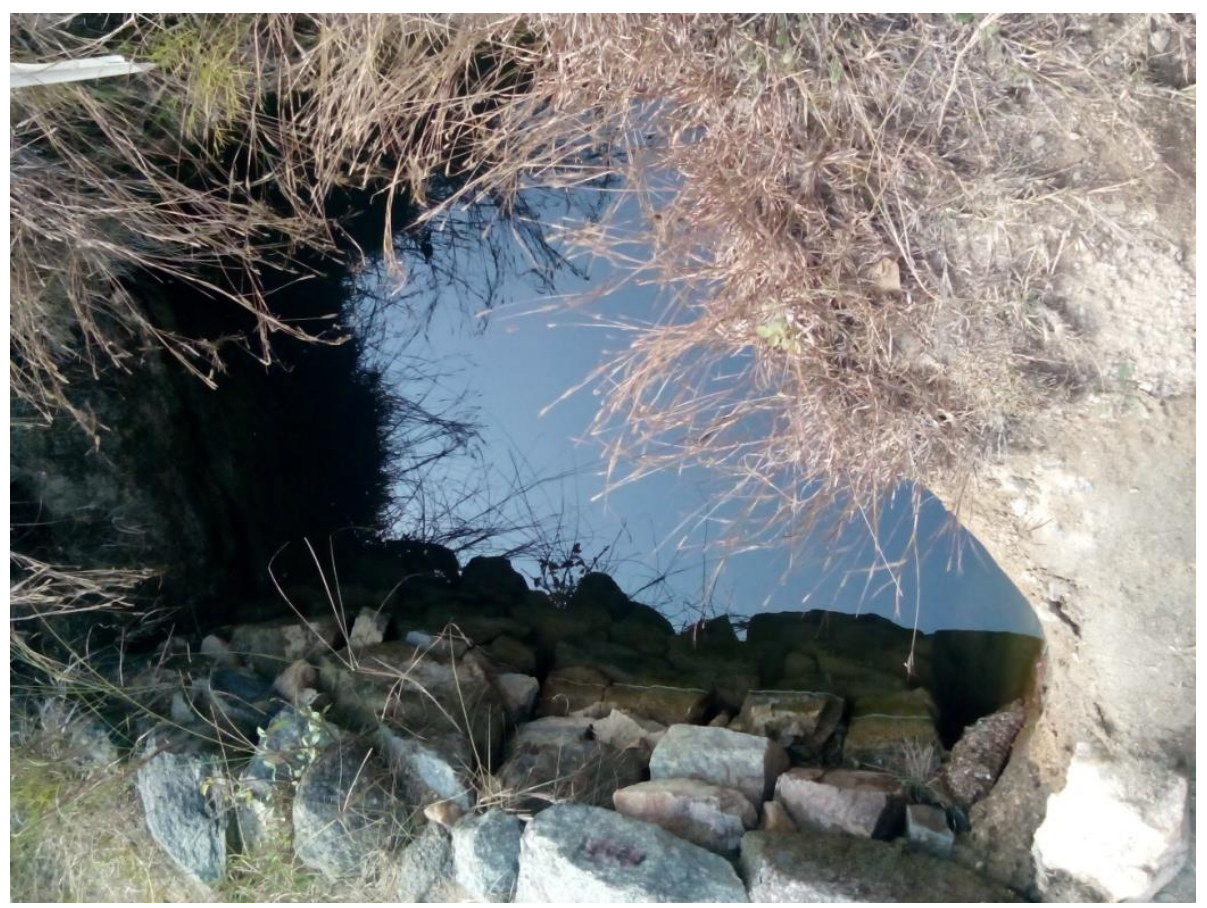

Figure 2: The makeshift well which was the prime source of drinking water to the members of the Birhor Tribe

Yet, drinking water was not their only problem. Proper food was a far-fetched idea. Despite a government scheme that guaranteed food grains and raw food products to people living below the poverty line (BPL), the people living in Birhortola did not receive the same. The local dealer would keep half of what was supposed to go the people and would give them half of the ration. They would have bought the ration separately, if they were given employment in nearby government projects, which, incidentally, also happens to be a government run scheme.

However, the builders and engineers usually got cheaper labour from their own areas and saved the funds for their own pockets. Thus, in the absence of employment and a fixed flow of income, the people usually had to rely on woodcutting and any form of job which could at least pay for a couple of days' meals. Since, that too, was a rarity; the natives would hunt wild rats, roast them and eat them for meals, as shown in figure 3 below. 

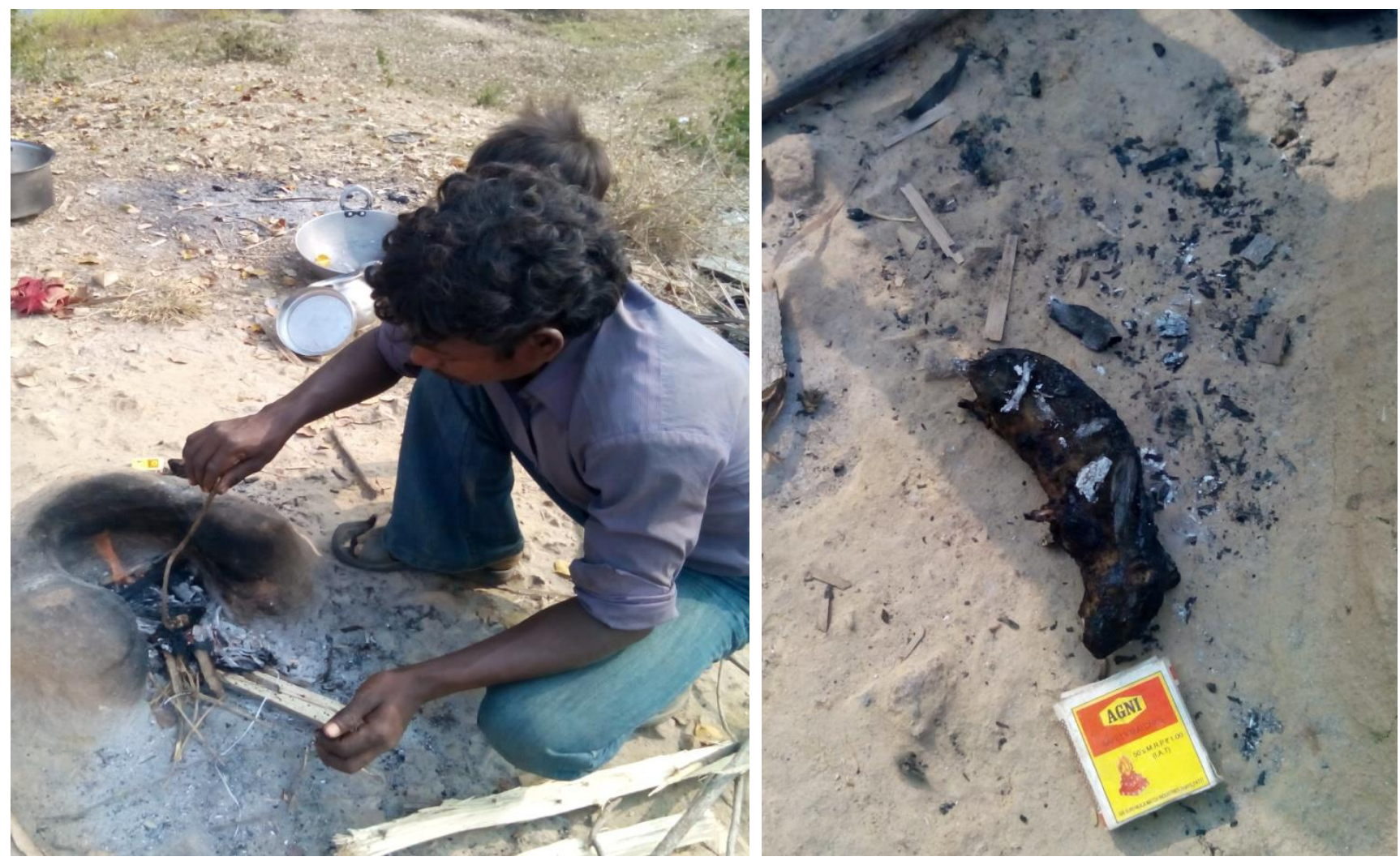

Figure 3: A member of the Birhor tribe roasting a wild rat that he caught, which would be his family's mid day meal

Similar was the case with health facilities. The block health centre had one ambulance, and to call for that the natives need mobile phone connections. Imagine the audacity of expecting the people who cannot afford three square meals to own a cell phone to avail basic health facilities. The state promises each and every of these basic amenities to the people of the country, rich or poor. There are also government schemes to fulfil these promises in some cases. But all the effort is lost somewhere between the implementing authorities and their agents, and the uneducated, naïve tribal natives of the area.

So what is the reason that these implementing authorities and their agents do not give the natives what is rightfully theirs? What is the cause of this kind of oppression? What could possibly be the purpose of denying basic amenities to people? An exploration of various psychological theories led me to two potential theories: the need for power and the evolutionary perspective in the face of competition.

\section{The need for Power}

The concept of social power has been defined as "the ability of a person to produce intended effects on the behaviour or emotions of another person" (Winter 1973 as cited by Morgan et al, 1993). One of the most important aspects of power motivation is to control others. Any situation which gives one to exert any kind of control over another is grabbed with both hands by the former. Yet, this theory, like most psychological theories, has an individual-based application.

People with high power motivation take up jobs that have high level of control and influence on others. According to McClleland (1961), the most important aspect for this need is to exercise influence over others (Royle, 2012). McClleland (1961) also states that the need for power refers to "make others behave as they wouldn't have otherwise". If we try and understand the story of the Birhors with reference to this theory, the people in power: the authority, the government agents and the local dealers, all enjoy the feeling of control over the tribal natives. It fulfils their need for power. 
And this is seen in any situation in the present day. The moment an opportunity arrives where one person can exercise power over the other, even if it be the power of advice, the former uses it to influence the latter's behaviour in such a way that it resonates the formers behaviour. Our need to control and influence others' behaviour also derives from the basic need of belongingness as explained by Maslow. An interaction of an individual with his or her society entails a to and fro relationship of power.

\section{The evolutionary perspective}

According to the concept of evolution, once population began to grow, and resources were limited, there arose a feeling of competition among human beings. This is also applied to the biological basis of aggression, where, since they were to woo the same mate, men showed aggression towards men, but not towards women. This is also one of the primary causes of prejudice. It states that everything that is the desire of human beings today is limited, and hence there is a competition for the same. And this competition is a primary source of prejudice (Baron, Byrne and Branscome, 2008).

Aggression has been defined as 'behaviour directed towards harming the other' (Baron, Byrne and Branscome, 2008). Whether oppression can be termed as aggression is a debatable question, but there can be no doubt that oppression is a result of discrimination. Discrimination emerges from prejudice and has been defined as "Unjustified negative or harmfulaction toward a member of agroup solely because of his or hermembership in that group" (Aronson, Wilson and Akert, 2013).

This theory might not be directly related to the study on the Birhors in Jharkhand, but it cannot be rendered completely redundant. True, that the people in authority may not be trying to tap the basic resources like water and food, but they too are fighting for one common benefit: money. Underlying this fight is a very prevalent caste system of India which also makes the authority unwilling to help the tribals, who hold a lower status in the social structure.

\section{Conclusion}

No matter how many theories are extended and debated over, one thing that can be said with complete certainty is that oppression is omnipresent. Arguments like "oppression is just a state of mind" and "The ones claiming to be oppressed also indulge in oppression" can change the fact that it is a reality, even in today's time. The human behaviour in its entirety will prove that an individual's traits and personality type could also be the contributing factor for his or her indulgence in an oppressive kind of behaviour. However, it would be wrong to only take the individual perspectives into account, because oppression is not just an individualistic issue.

It is a social problem, which has been going on forever, and hence there is a need to study oppression from psychological, sociological as well as legal perspectives. The members of the Birhor tribes were not only being wronged due to individual traits of the oppressors. They were being wronged because there exists an orthodox caste system in the Indian society. Also, right to basic amenities is a fundamental right protected by the constitution of the country, and that too, is being violated in this case. Thus, there lies a need for an interdisciplinary approach when we try to study and, more importantly, combat the universal problem of oppression.

The present study started from the contention that oppression is not a thing of the past. The study discussed is a present day study which covers a real life condition of oppression of one group of people by those in power. The present study also raised the question regarding the cause behind this permanent existence of oppression in the society. Upon analysing, the conclusion that can be arrived at, is that the structure of the society, the understanding of social phenomenon and the individual capacity, all play a role in continuing this behaviour to exist. The aim of the present study was to present a psychosocial causation of oppressive behaviour in human 
beings. The study concludes that oppression is a behaviour that human being has acquired through the process of evolution and which develops through socio-cultural interactions of the person.

\section{References}

Aronson, E., Wilson, T.D., \&Akert, R.M. (2013). Prejudice: Caues, consequences and cues.Social Psychology (8th Ed.). Pearson Education Inc.

Baron, R.A. (2015). Motivation and Emotion. Psychology (5 ${ }^{\text {th }}$ Ed.). Pearson Education Inc.

Baron, R.A., Byrne, D., \&Branscome, N.L. (2008). Aggression: Its nature, causes and control. Social Psychology (11 ${ }^{\text {th }}$ Ed.). Dorling Kindersley (India) Pvt. Ltd.

Baron, R.A., Byrne, D., \&Branscome, N.L. (2008). Prejudice: Its causes, effects and cures. Social Psychology $\left(11^{\text {th }}\right.$ Ed.). Dorling Kindersley (India) Pvt. Ltd.

Bohmer, S. \&Briggs, J.L. (1991) Teaching Privileged Students about Gender, Race, and Class Oppression. Teaching Sociology, 19(2), 154-163.

Frye, M. (1983). Oppression. Gender Basics: Feminist Perspective on Women and Men, (2 ${ }^{\text {nd }}$ Ed.), 10-16.

Gillingham, E. (2012). Frye's Oppression: An Inadequate Definition. Retrieved September 17, 2017 from http://em-journal.com/2012/03/fryes-oppression-an-inadequate-definition-1.html

Gilson, E. (2011). Vulnerability, Ignorance, and Oppression. Hypatia, 26(2), 308-332.

McClelland, D. (1961). The achieving society. Princeton, NJ: Van Nostrand Company Inc.

Morgan, C.T., King, R.A., Weisz, J.R. \&Schopler, J. (1993). Motivation. Introduction to Psychology (7th Ed). New Delhi: Tata McGraw-Hill Publishing Company Limited.

Myers,D.G. (1990). Social Psychology. (3 $3^{\text {rd }}$ Ed.). New York: Tata McGraw-Hill.

Prilleltensky, I.\&Gonick, L.(1996). Polities Change, Oppression Remains: On the Psychology and Politics of Oppression. Political Psychology, 17(1), 127-148.

Royle, M.T. (2012) The relationship between Mcclelland's theory of needs, feeling individually accountable, and informal accountability for others. International Journal of Managing and Marketing Research, 5(1), 21-42.

Definitions of Oppression, Dehumanization and Exploitation. Retrieved September 17, 2017 from http://www.personal.umich.edu/ mdover/website/Oppression\%20Compendium\%20and\%20Materials/Definitio ns\%20of\%20Oppression.pdf

$\begin{array}{lccccc}\begin{array}{l}\text { Social } \\ \text { http://home.earthlink.net/ clevy/Social_Stratification }\end{array} & \begin{array}{c}\text { Retrieved } \\ \text { Chapter_8_.pdf }\end{array} & \begin{array}{c}\text { September } \\ \text { Chation. }\end{array} & 16, & 2017 & \text { from }\end{array}$

